\title{
Impacts of Feeding Three Commercial Trout Starter Diets to Rainbow Trout on Bacterial Coldwater Disease-Induced Mortality
}

\author{
Cody E. Treft ${ }^{1}$, Michael E. Barnes²*, Jill M. Voorhees ${ }^{1}$, Tabor J. Martin ${ }^{1}$, Brian L. Fletcher ${ }^{1}$
}

${ }^{1}$ South Dakota Department of Game, Fish, and Parks, Cleghorn Springs State Fish Hatchery, 4725 Jackson Blvd. Rapid City, South Dakota 57703 USA

${ }^{2}$ South Dakota Department of Game, Fish, and Parks, McNenny State Fish Hatchery, 19619 Trout Loop, Spearfish, South Dakota 57783 USA

*Corresponding author: Michael E. Barnes, South Dakota Department of Game, Fish and Parks, McNenny State Fish Hatchery, 19619 Trout Loop, Spearfish, South Dakota, 57783 USA, Tel: 1-605-642-1262; E-mail: mike.barnes@state.sd.us

\begin{abstract}
Bacterial Coldwater Disease, an infection caused by Flavobacterium psychrophilum, causes substantial mortality during the initial feeding of salmonids in hatcheries around the world. This study evaluated the potential impacts of three commercial starter diets on Bacterial Coldwater Disease-induced mortality during rainbow trout (Oncorhynchus mykiss) rearing. Two Bio Oregon (Longview, Washington, USA) diets, Bio-Vita and BioPro2, and Skretting (Toele, Utah, USA) Starter Crumble were fed for 71 days. Mortality due to F. psychrophilum began to sharply increase 14 days after the start of the trial. Mean mortality in the tanks receiving Skretting Starter Crumble was $69.8 \%$, which was significantly higher than the $55.4 \%$ mean mortality observed in the tanks of trout fed Bio-Vita. Mean mortality in the BioPro2-fed tanks was $58.0 \%$, and was not significantly different than that observed in the tanks receiving the other two diets. Rainbow trout lengths and weights at the end of the study were not significantly different among the dietary treatments. To minimize mortality due to Bacterial Coldwater Disease, rainbow trout should receive Bio-Vita beginning at initial feeding. However, as indicated in this study, diet alone is not enough to fully manage Bacterial Coldwater Disease, necessitating the use of additional therapeutic actions.
\end{abstract}

Received date: June 09, 2015

Accepted date: August 12, 2015

Published date: August 17, 2015

Citation: Barnes, M.E., et al. Impacts of Feeding Three Commercial Trout Starter Diets to Rainbow Trout on Bacterial Coldwater Disease-Induced Mortality. (2017) J Marine Biol Aquacult 3(2): 1- 5.

DOI: $10.15436 / 2381-0750.17 .1501$

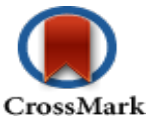

Keywords: Bacterial coldwater disease; Flavobacterium psychrophilum; Rainbow trout; Oncorhynchus mykiss; Diet

\section{Introduction}

Bacterial Coldwater Disease (BCWD) is caused by Flavobacterium psychrophilum, and exhibits a profound impact on salmonid culture worldwide ${ }^{[1-4]}$. The disease typically results in 10 to $30 \%$ fry mortality, but losses of up to $70 \%$ have been reported $^{[5]}$. While BCWD, also known as Rainbow Trout Fry Syndrome, affects many different salmonid species, juvenile rainbow trout (Oncorhynchus mykiss) are particularly susceptible ${ }^{[3,4]}$.

Antibiotics are commonly used to treat BCWD infections, but Flavobacterium psychrophilum quickly develops antibiotic resistance ${ }^{[5,6]}$. In addition to antibiotics, improved water quality, decreased fish handling, and prompt mortality removal may all possibly alleviate the negative effects of BCWD (Cipria- no and Holt, 2005; Barnes and Brown 2011; Starliper 2001). Nutrition has been suspected as a possible influence of the disease by Barnes and Brown (2011), but there is an absence of studies evaluating the effects of diet on BCWD.

Cleghorn Springs State Fish Hatchery, Rapid City, South Dakota, USA experiences substantial mortality in juvenile rainbow trout due to BCWD. (Neiger, et al. 2016) Changes in fish husbandry practices have not affected disease outbreaks at the Cleghorn Hatchery. However, the recent availability of multiple commercial diets provided the opportunity to evaluate potential dietary influences on BCWD. Thus, the objective of this study was to examine the effects of feeding different commercially available diets on rainbow trout mortality. 


\section{Materials and Methods}

This 71-day study was conducted at Cleghorn Springs State Fish Hatchery, Rapid City, South Dakota, USA, using $11^{\circ} \mathrm{C}$ spring water (total hardness as $\mathrm{CaCO}_{3}, 36 \mathrm{mg} \mathrm{L}^{-1}$; alkalinity as $\mathrm{CaCO}_{3}, 210 \mathrm{mg} \mathrm{L}^{-1} ; \mathrm{pH}, 7.6$; total dissolved solids, $390 \mathrm{mg} \mathrm{L}^{-1}$ ). Shasta strain rainbow trout (Oncorhynchus mykiss) eggs were hatched in vertical flow incubators (Mari Source, Fife, Washington, USA). On March 2, 2016, swim-up fry were pooled into a $1.61 \mathrm{~m}^{3}$ diameter circular tank. The following day, 1,000 fry (mean \pm SE, weight $0.12 \pm 0.02$ grams, length $25.1 \pm 1.4 \mathrm{~mm}, \mathrm{~N}$
$=30$ ) were placed into each of 12 semi-square 190-liter tanks. Incoming water flows were set at $8 \mathrm{~L} / \mathrm{min}$.

Each of the twelve tanks was assigned one of three dietary treatments $(\mathrm{N}=4)$, with each treatment a distinct commercial feed sequence of starter $(\# 0)$, and \#1 granules. The treatments consisted of either Skretting Starter Crumble (Toele, Utah, USA), BioPro 2 (Bio-Oregon, Longview, Washington, USA), or Bio-Vita Crumble (Bio-Oregon, Longview, Washington, USA). Tables 1 and 2 list the guaranteed analysis and ingredients for each diet, as reported by the manufacturer.

Table 1: Guaranteed analysis, as provided by the manufacturers of the feeds used in this study.

\begin{tabular}{|c|l|c|c|c|c|c|c|c|}
\hline Treatment & Feed & \multicolumn{1}{l|l}{ Size } & Protein & Fat & Fiber & Ash & Moisture & Digestible Energy \\
\hline 1 & Skretting & $\# 0$ & $52 \%$ & $16 \%$ & $1 \%$ & $12 \%$ & $8 \%$ & $17.9(\mathrm{MJ} / \mathrm{kg})$ \\
\hline 1 & Skretting & $\# 1$ & $52 \%$ & $16 \%$ & $1 \%$ & $12 \%$ & $8 \%$ & $17.9(\mathrm{MJ} / \mathrm{kg})$ \\
\hline 2 & BioPro2 & $\# 0$ & $53 \%$ & $18 \%$ & $1 \%$ & $12 \%$ & $8.5 \%$ & $18.9(\mathrm{MJ} / \mathrm{kg})$ \\
\hline 2 & BioPro2 & $\# 1$ & $52 \%$ & $20 \%$ & $1 \%$ & $12 \%$ & $8.5 \%$ & $19.3(\mathrm{MJ} / \mathrm{kg})$ \\
\hline 3 & Bio-Vita & $\# 0$ & $53 \%$ & $18 \%$ & $1 \%$ & $12 \%$ & $8.5 \%$ & $18.9(\mathrm{MJ} / \mathrm{kg})$ \\
\hline 3 & Bio-Vita & $\# 1$ & $52 \%$ & $20 \%$ & $1 \%$ & $12 \%$ & $8.5 \%$ & $19.3(\mathrm{MJ} / \mathrm{kg})$ \\
\hline
\end{tabular}

Table 2: Ingredient lists, as stated, in order on manufacturer's size \#0 ingredient label.

\begin{tabular}{|c|c|c|c|}
\hline \multirow[b]{2}{*}{ Feed Size } & \multicolumn{3}{|c|}{ Diet } \\
\hline & Skretting & BioPro2 & Bio-Vita \\
\hline \multirow[t]{13}{*}{ \#0 (starter) } & Fish Meal & Fish Meal & Fish Meal \\
\hline & Wheat Flour & Fish Oil & Fish Oil \\
\hline & Poultry By-Product Meal & Wheat Gluten & Wheat Flour \\
\hline & Fish Oil & Wheat Flour & Wheat Gluten \\
\hline & Squid Meal & Whey Powder & Dried Fish Solubles \\
\hline & Brewer's Yeast & Lecithin & Dried Whey Powder \\
\hline & Choline Chloride & Porcine Gelatin & Porcine Gelatin \\
\hline & L-Ascorbyl-2-Polyphosphate & Brewer's Yeast & Mono Ammonium Phosphate \\
\hline & Vitamin Premix & Vitamin/Mineral Premix & Vitamin/Mineral Premix \\
\hline & Ethoxyquin & Astaxanthin & Brewer's Yeast \\
\hline & & Natural/Artificial Flavoring & DL Methione \\
\hline & & & Astaxanthin \\
\hline & & Ethoxyquin & Ethoxyquin \\
\hline \multirow[t]{13}{*}{$\# 1$} & Fish Meal & Fish Meal & Fish Meal \\
\hline & Wheat Flour & Fish Oil & Fish Oil \\
\hline & Fish Oil & Wheat Flour & Wheat Flour \\
\hline & Feather Meal & Wheat Gluten & Wheat Gluten \\
\hline & Wheat Gluten & Whey Powder & Dried Fish Solubles \\
\hline & Poultry By-Product Meal & Porcine Gelatin & Dried Whey Powder \\
\hline & Brewer's Yeast & Lecithin & Porcine Gelatin \\
\hline & Squid Meal & Vitamin/Mineral Premix & Mono Ammonium Phosphate \\
\hline & L-Lysine Hydrochloride & Brewer's Yeast & Vitamin/Mineral Premix \\
\hline & L-Ascorbyl-2-Polyphosphate & Astaxanthin & Brewer's Yeast \\
\hline & Ethoxyquin & Natural/Artificial Flavoring & DL Methionine \\
\hline & & Ethoxyquin & Astaxanthin \\
\hline & & & Ethoxyquin \\
\hline
\end{tabular}

Feed was administered every 90 minutes using 0.5 liter vibratory feeders (Pentair Aquatic Eco-Systems, Inc., Apopka, Florida, USA) connected to a timer (Sweeney Enterprises Inc., Boerne, TX, USA). Feed amounts for all tanks for the first week were based on an initial growth rate of $0.025 \mathrm{~cm} /$ day at a projected feed conversion of 1.1, with feeding to satiation for the remainder of 
the study. Feed was weighed to the nearest 0.1 gram daily. On study day 43, feed sizes were increased from starter to \#1 for each of the feeds. Tanks were all cleaned at the same interval throughout the study.

Mortalities were removed and recorded daily. When mortality began to sharply increase at day 14 , bacteriological samples were collected and shipped to the Washington Animal Disease Diagnostic Laboratory (Pullman, Washington, USA) for confirmation of the presence of Flavobacterium psychrophlium. The study continued until mortality was deemed negligible. At the end of the study, five fish were weighed to the nearest $0.01 \mathrm{~g}$ and total length measured to the nearest $0.1 \mathrm{~mm}$ from each tank.

Mortality data was analyzed using one-way Analysis of Variance (ANOVA) and Tukey's mean comparison procedure. Percent mortality data was log transformed prior to analysis to stabilize variances. Significance was predetermined at $p<0.05$

\section{Results and Discussion}

Total mortality for the duration of the trial was significantly different among the treatments (Figure 1). Percent mortality was significantly higher for fish fed the Skretting starter crumble diets than fish fed Bio-Vita, while mortality in the tanks fed BioPro 2 was not significantly different from the other two diets. Mortality began to sharply increase on day 14 , when fish began exhibiting symptoms (increased pigmentation, erratic swimming, lethargy, pale gills, and lesions on mortalities) of $\mathrm{BCWD}^{[2-4]}$ (Starliper 2011). The presence of $F$. psychrophilum was confirmed. Fish lengths (Figure 2) and weights (Figure 3) at the conclusion of the study were not significantly different among the treatments.

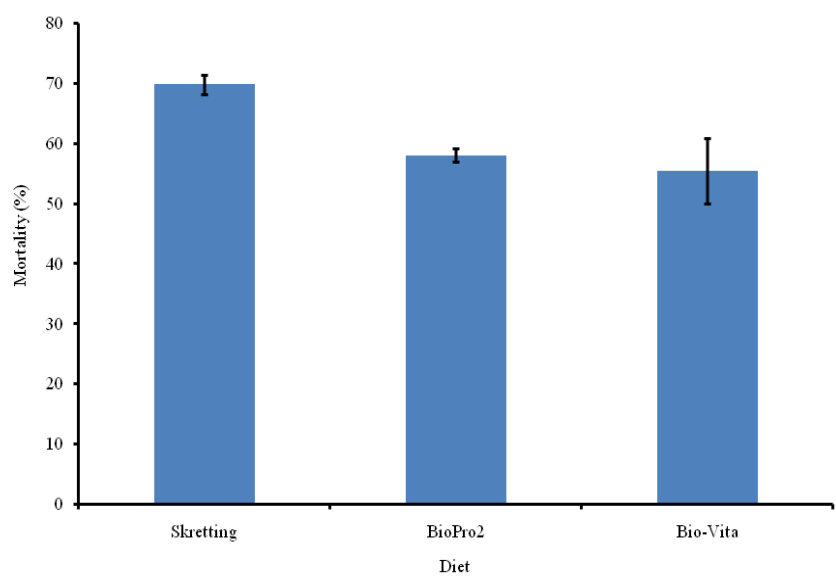

Figure 1: Mean $( \pm \mathrm{SE})$ total mortality (\%) from tanks of rainbow trout fed one of three commercial diets for 71 days from initial feeding, with sizes $\# 0$ and $\# 1$ combined. Means with different letters are significantly different $(\mathrm{N}=4, \mathrm{P}=0.030)$.

The results from this study clearly indicate a dietary influence on BCWD-induced mortality. The differences in mortality are likely not due to the gross nutritional characteristics of the diet. The proximate analysis of each diet was very similar, with each diet meeting or exceeding the nutritional requirements for protein and lipids of rainbow trout ${ }^{[7]}$. All diets also meet the threshold of 45 to $55 \%$ protein for trout fry in the first eight weeks of feeding identified by Piper et al. (1982). However, overall digestible energy in both of the Bio-Oregon products is greater than in the Skretting diets.

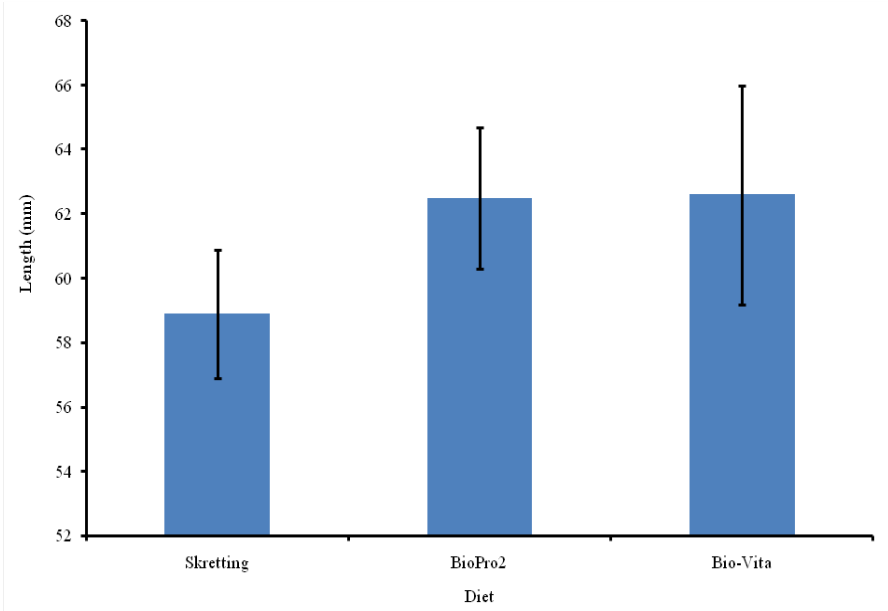

Figure 2: Mean $( \pm \mathrm{SE})$ total length $(\mathrm{mm})$ of rainbow trout from tanks receiving one of three commercial diets for 71 days from initial feeding, with sizes \#0 and \#1 combined $(\mathrm{N}=4, \mathrm{P}=0.432)$.

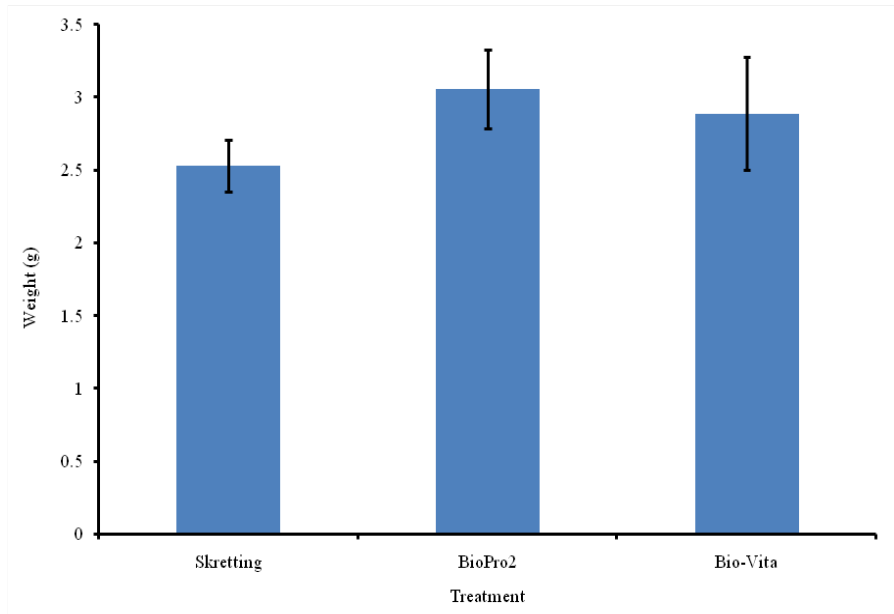

Figure 3: Mean $( \pm \mathrm{SE})$ weight $(\mathrm{g})$ of rainbow trout from tanks receiving one of three commercial diets for 71 days from initial feeding, with sizes $\# 0$ and $\# 1$ combined $(\mathrm{N}=4, \mathrm{P}=0.293)$.

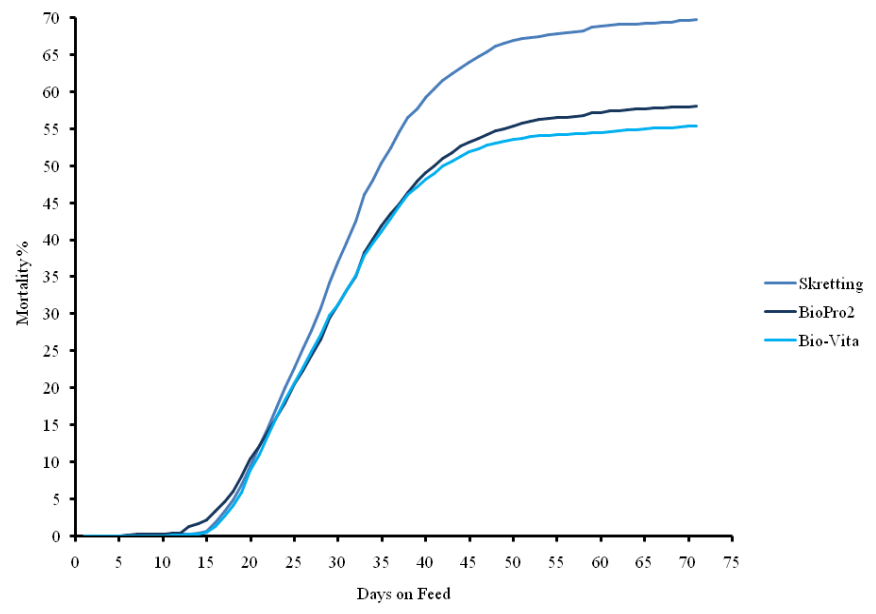

Figure 4: Cumulative mortality (\%) of rainbow trout fed one of three commercial diets for 71 days from initial feeding.

The gross nutritional features of the diets are similar, 
but there are differences in the dietary ingredients. Although fish meal is the first ingredient on all diets, in the Bio-Vita and BioPro 2 diets fish oil is listed as the second ingredient, while the Skretting diet lists fish oil as the fourth most abundant ingredient, after wheat flower and poultry by-product meal. In addition to poultry by-product meal, Skretting also utilizes feather meal and squid meal as dietary protein sources. Historically, rendered animal protein digestibility and quality has widely varied in terms of digestibility, and nutritive value ${ }^{[7,8]}$. Dong et al. $(1993)^{[9]}$ also suggests that the proximate composition of poultry by-product meal varies from manufacturer to manufacturer. However, more standardized manufacturing practices have increased the quality and digestibility of these greatly, making it a viable option for replacing fishmeal in small quantities ${ }^{[10]}$. The relatively higher amount of fish oil in the Bio-Oregon diets is potentially the reason for the higher digestible energy values in these diets.

Differences in the minor, by weight, ingredients among the diets may help explain the differences in BCWD mortality. Unlike the Skretting diet, Bio-Vita and BioPro 2 contain astaxanthin, whey powder, and porcine gelatin. Skretting also contains squid meal, BioPro2 contains lecithin, and Bio-Vita contains fish solubles. Of particular interest is astaxanthin. Astaxanthin, a carotenoid precursor to vitamin $\mathrm{A}$, is frequently used as a fillet colorant $^{[7]}$. More importantly, it likely enhances immune function by helping to modulate macrophage and lymphatic action, increasing immunity to tumors, and increasing respiratory function under decreased oxygen conditions ${ }^{[7,11]}$. In a trial involving Atlantic salmon (Salmo salar) fry, Christiansen et al. (1994) ${ }^{[12]}$ concluded that a lack of astaxanthin in casein diets led to low survival and very poor growth during the initial feeding stage. Astaxanthin has even been suggested as being listed as a vita$\min ^{[7]}$. While not definitive, astaxanthin could have played a major role in reducing mortality in this study.

Another potentially valuable ingredient, lecithin, is found in the BioPro2 diet. Lecithin is the main phospholipid in many cell membranes, and aids entry of compounds into cells [3,13]. When included in diets as a phospholipid, there has been improved growth, increased survival rates, decreased malformation, and my increase resistance to stress in certain fish species (National Research Council 2011).

All diets possess ingredients thought to contain unidentifiable growth factors; Skretting Classic contains squid meal, BioPro2 contains whey powder, and Bio-Vita contains both whey powder and dried fish solubles. Although being initially described nearly 100 years ago, little research has been conducted on these factors in aquaculture feeds ${ }^{[13]}$. UGF have been suspected to increase fish growth.

Squid meal, derived from squid viscera, is very high in protein ( $70 \%$ to $90 \%$ ), with protein content attributing to approximately $84 \%$ of its gross energy ${ }^{[13]}$. In addition, with larval feed inclusion rates as high as $20 \%$ to $30 \%$, squid meal is also thought to be a chemo-attractant ${ }^{[13]}$. Similar to squid meal, dried fish solubles are a fish meal manufacturing by-product, and provide essential amino acids while acting as a UGF. Fish solubles also dually serve to act as a pellet binder, and increase overall diet palatability ${ }^{[13]}$. Whey powder, a carbohydrate source isolated from milk, is a lower protein ingredient also believed to be a supplier of unidentifiable growth factors, and can be included at rates of up to $10 \%$ for salmonids.

Both Bio-Oregon diets contain porcine gelatin. It is a protein binder, which has a high digestibility and slight nutritional value making it suitable for carnivorous fish $\operatorname{diets}^{[14]}$. Porcine gelatin is absent from the Skretting diets.

While fish mortalities due to amino acid and essential fatty acid deficiency are rare, losses due to vitamin and mineral deficiencies are more common ${ }^{[15]}$. These deficiencies can arise from vitamin and mineral premixes, or from antagonistic interactions with other ingredients in the $\operatorname{diet}^{[15]}$. In addition to the vitamins and minerals present in the premixes, the dietary contributions of vitamins and minerals of present feed ingredients usually are not usually taken into consideration ${ }^{[7]}$. The composition of the premixes used in the diets studied is unknown, making it impossible to determine what part, if any, they may have played in the observed mortality.

Shasta strain rainbow trout were used in this trial, but additional trials with different strains of rainbow trout may have produced different results ${ }^{[16]}$. Other characteristics of this study, such as water chemistry ${ }^{[16-18]}$ and fish rearing densities ${ }^{[4,18]}$, may have also influenced the results. Lastly, the strain of F. psychrophilum in this trial is unique ${ }^{[19-21]}$, and less virulent strains may react differently to different diets.

Results from this feeding trial indicate Bio-Vita was the most effective diet for reducing BCWD mortality. However, dietary changes alone were not enough of a factor to alleviate substantial mortality. Despite being most effective at controlling BCWD-induced mortality, Bio-Vita still experienced greater than 50 percent loss. If the primary concern of hatchery management is controlling mortality due to Bacterial Coldwater Disease, Bio-Vita should be considered as a starter feed. If BCWD - induced mortality is not a concern, all feeds used in this trial are acceptable. 


\section{References}

1. Aoki, M., Kondo, M., Kenji, K., et al. Experimental bath infection with Flavobacterium psychrophilum, inducing typical signs of rainbow Oncorhynchus mykiss fry syndrome. (2005) Dis Aquat Organ 67(1-2): 73-79.

Pubmed | Crossref | Others

2. Barnes, M.E., Brown, M.L. Flavobacterium psychrophilum biology, clinical signs, and bacterial coldwater disease prevention and treatment. (2011) Open Fish Sc J 4: 40-48.

Pubmed $\mid$ Crossref $\mid$ Others

3. Brown, P.B., Wilson, K.A., Hodgin, Y., et al. Use of soy protein concentrates and lecithin products in diets fed to coho and Atlantic salmon. (1997) J Am Oil Chemists' Soc 74(3): 187-193. Crossref | Others

4. Cipriano, R.C., Holt, R.A. Flavobacterium psychrophilum, cause of bacterial cold-water disease and rainbow trout fry syndrome. (2005) US Dept Interior US Geol Service Nat Fish Health Res Lab Fish Disease Leaflet No. 86.

Pubmed | Crossref $\mid$ Others

5. Faruk, MAR. A review on Rainbow Trout Fry Syndrome (RTFS). (2002) Pak J Biol Sci 5(2): 230-233.

Others

6. Madetoja, J., Dalsgaard, I., Wiklund, T. Occurence of Flavobacterium psychrophilum in fish-farming Environments. (2002) Dis Aquat Organ 52(2): 109-118.

Pubmed | Crossref

7. Bureau, D.P., Harris, A.M., Cho, C.Y. Apparent digestibility of rendered animal protein ingredients of rainbow trout (Oncorhynchus mykiss). (1999) Aquaculture 180: 345-358.

Crossref | Others

8. Bureau, D.P., Harris, A.M., Bevan, D.J., et al. Feather meals and meat and bone meals from different origins as protein sources in rainbow (Oncorhynchus mykiss) diets. (2000) Aquaculture 181: 281-291.

Crossref | Others

9. Christiansen, R., Lie, O., Torrissen, O.J. Effect of astaxanthin and vitamin A on growth and survival during first feeding of Atlantic salmon Salmo salar L. (1994) Aquacult Fish Manage 25(9): 903-914.

Crossref | Others

10. Dong, F.M., Hardy, R.W., Haard, N.F., et al. Chemical composition and protein digestibility of poultry by-product meals for salmonid diets. (1993) Aquaculture 116(2-3): 149-58.

Crossref | Others
11. Groff, J.M., LaPatra, S.E. An Overview of the Economically Important Diseases of Salmonids. Nutrition and Fish Health. In Nutrition and Fish Health (Lim C, Webster CD, eds.). (2001) Binghamton, NY: Food Products Press pp: 11-78.

Pubmed | Crossref $\mid$ Others

12. Hardy, R.W. Nutritional Deficiencies in Commercial Aquaculture: Likelihood, Onset, and Identification. In Nutrition and Fish Health (Lim C, Webster CD, eds.). (2001) Binghamton, NY: Food Products Press 131-147.

Pubmed | Crossref | Others

13. Hertrampf, J.W., Piedad-Pascual, F. Handbook on Ingredients for Aquaculture Feeds. (2000) Springer Science and Business Media.

Crossref

14. National Research Council. Nutrient Requirements of Fish and Shrimp. (2011) Washington, DC: National Academy Press. Others

15. Neiger, R., Thomas, M., Das, S., et al. Draft genome sequences of three Flavobacterium psychrophilum strains isolated from coldwater disease outbreaks at three production hatcheries. (2016) Genome Announc 4(2): e00035-16.

Pubmed | Crossref | Others

16. Paolucci, M., Fabbrocini, A., Volpe, M.G., et al. Development of biopolymers as binders for feed for farmed aquatic organisms. (2012) In Aquaculture, InTech.

Crossref | Others

17. Piper, R.G., McElwain, I.B., Orme, L.E., et al. Fish hatchery management. (1982) Washington, DC: US Government Printing Office.

Others

18. Post, G. Textbook of Fish Health. (1987) TFH Publication. Inc, Neptune City, New Jersey.

Pubmed $\mid$ Crossref $\mid$ Others

19. Silverstein, J.T., Vallejo, R.L., Palti, Y., et al. Rainbow trout resistance to bacterial cold-water disease is moderately heritable and is not adversely correlated with growth. (2009) J Anim Sci 87(3): 860-867.

Pubmed | Crossref | Others

20. Taylor, P.W. Detection of Flavobacterium psychrophilum in eggs and sexual fluids of Pacific salmonids by a polymerase chain reaction assay: implications for vertical transmission of bacterial coldwater disease. (2004) J Aquat Anim Health 16(2): 104-108.

Crossref | Others

21. Torrissen, O.J. Pigmentation of salmonids: effect of carotenoids in eggs and start feeding diet on survival and growth rate. (1984) Aquaculture 43(1-3): 185-193.

Crossref | Others

Journal ISSN 2381-0750

E-mail: marinelife@ommegaonline.org

Website: www.ommegaonline.org
Journal Title: Journal of Marine Biology and Aquaculture

Journal Short Name: J Marine Biol Aquacult 